\title{
Effect of Basicity and Structure on the Hydration of Protonated Molecules and Cluster Formation: An Ion Mobility-Time of Flight Mass Spectrometry and Theoretical Study
}

\author{
Younes Valadbeigi ${ }^{\dagger *}$, Vahideh Ilbeigi ${ }^{\ddagger}$, Bartosz Michalczuk ${ }^{\S}$, Martin Sabo ${ }^{\S}$, Stefan Matejcik ${ }^{\S}$ \\ 'Department of Chemistry, Faculty of Science, Imam Khomeini International University, Qazvin, Iran. \\ TOF Tech. Pars Company, Isfahan science \& Technology Town, Isfahan, Iran. \\ ${ }^{\S}$ Department of Experimental Physics, Comenius University, Mlynska dolina F2, 84248 Bratislava, \\ Slovak Rep.
}

\section{Corresponding authors:}

(Y.V.) E-mail: y.valadbeigi@ch.iut.ac.ir; Phone: +98 2833901367.

(S. M.) E-mail: stefan.matejcik@fmph.uniba.sk; Phone: +421260295686.

\begin{abstract}
Protonation, hydration and cluster formation of ammonia, formaldehyde, formic acid, acetone, butanone, 2-ocatanone, 2-nonanone, acetophenone, ethanol, pyridine and its derivatives were studied by IMS-TOFMS technique equipped with a corona discharge ion source. It was found that tendency of the protonated molecules, $\mathrm{MH}^{+}$, to participate in hydration or cluster formation depends on the basicity of $\mathrm{M}$. The molecules with higher basicity were hydrated less than those with lower basicity. The mass spectra of the low basic molecules such as formaldehyde exhibited larger clusters of $\mathrm{M}_{\mathrm{n}} \mathrm{H}^{+}\left(\mathrm{H}_{2} \mathrm{O}\right)_{\mathrm{n}}$ while for compounds with high basicity such as pyridine only $\mathrm{MH}^{+}$ and $\mathrm{MH}^{+} \mathrm{M}$ peaks were observed. The results of DFT calculations confirm that enthalpies of hydrations and cluster formation decrease as basicities of the molecules increases. Using comparison of mass spectra of formic acid, formaldehyde, and ethanol, effect of structure on the cluster formation was investigated. Formation of symmetric $\left(\mathrm{MH}^{+} \mathrm{M}\right)$ and asymmetric protonbound dimers $\left(\mathrm{MH}^{+} \mathrm{N}\right)$ was studied by ion mobility and mass spectrometry techniques. Both theoretical and experimental results shows that asymmetric dimers are formed more easily between molecules $(\mathrm{M}$ and $\mathrm{N}$ ) with comparable basicity. As the basicity different between $\mathrm{M}$ and $\mathrm{N}$ increases, the enthalpy of $\mathrm{MH}^{+} \mathrm{N}$ formation decreases.
\end{abstract}

Keywords: Proton affinity; Clustering; Hydration; Proton-bound dimer; Mass spectrometry. 


\section{Introduction}

Ion-molecules reactions play crucial roles in many phenomena occurring in atmosphere and living systems [1-4]. Among these reactions, proton transfer has been well studied and more considered [5-8] because of its importance and applications in biology, environmental sciences, and chemistry.

Theoretical and experimental studies show that proton can be hydrated to form hydronium clusters $\left(\mathrm{H}_{2} \mathrm{O}\right)_{\mathrm{n}} \mathrm{H}_{3} \mathrm{O}^{+}$, with different numbers of water molecules [9-11]. Konig and Fales [9] studied hydronium ions with up to 222 water molecule using quadrupole mass spectrometry. They showed that for medium-size clusters, those with 21 and 28 water molecules have more stability. A theoretical study on the hydronium ions with $21 \mathrm{H}_{2} \mathrm{O}$ molecule revealed that the $\mathrm{H}_{3} \mathrm{O}^{+}$ion tends to be located in the surface of the clusters [11]. Protonated molecules, $\mathrm{MH}^{+}$, are also hydrated in the presence of water, or form ionic clusters with other neutral molecules [12,13]. In the $\mathrm{M}_{n}\left(\mathrm{H}_{2} \mathrm{O}\right)_{\mathrm{m}} \mathrm{H}^{+}$ clusters with large numbers of water molecules, the proton tends to remain on the $\mathrm{H}_{3} \mathrm{O}^{+}$, even if $\mathrm{M}$ has high basicity $[8,14-16]$. In the $\mathrm{MH}^{+}\left(\mathrm{H}_{2} \mathrm{O}\right)_{\mathrm{n}}$ clusters with 1 or 2 water molecules, the proton usually remains on the M $[17,18]$. Hydration of protonated molecules influences their stability, and structural and thermodynamic properties $[19,20]$. Hydration of alkyl diammonium cations influences their structures so that the linear alkyl change is folded to form a bent structure $[19,21]$.

In mass spectrometers equipped with electrospray or corona discharge ionization sources the protonated molecules are often hydrated and they are observed as $\mathrm{MH}^{+}\left(\mathrm{H}_{2} \mathrm{O}\right)_{n}$ [22-24]. Amount of hydration is affected by temperature and water vapor content of the systems; so that lower temperature and higher water concentration increase hydration [25]. On the other hand, the hydration of different molecules at the same temperature and the same water pressure is different 
[18]. Therefore, other than temperature and water concentration, amount of hydration depends on the nature of the molecule, which is discussed in this paper.

Protonated molecules, $\mathrm{MH}^{+}$, also form proton-bound dimers in the presence of excess amount of the neutral molecule, $\mathrm{M}[26,27]$,

$\mathrm{MH}^{+}+\mathrm{M} \rightarrow \mathrm{MHM}^{+}$

In the presence of extra amount of M, reaction (1) may proceed to form proton-bound trimmers [28]. However, it is reported that the proton-bound trimers are not stable and have short lifetime so that they are observed at lower temperatures in the presence of higher vapor concentration of the sample [29]. Many researchers have reported that the proton-bound dimers are rarely hydrated or hydration destroys these dimers [25,30,31]. Asymmetric proton-bound dimers are also observed in ion mobility (IMS) and mass spectrometry (MS) studies [28]

$\mathrm{MH}^{+}+\mathrm{N} \rightarrow \mathrm{MHN}^{+}$

However, formation of asymmetric proton-bound dimers, $\mathrm{MHN}^{+}$, is not as easily as that of symmetric proton-bound dimers, $\mathrm{MHM}^{+}$[32-34], so that the former are formed with only some special $\mathrm{M}$ and $\mathrm{N}$ molecules.

In this work, hydration of different protonated molecules is studied using IMS and MS techniques and DFT methods. The amount of hydration of the protonated molecules, $\mathrm{MH}^{+}$, is discussed based on the basicity and structure of the neutral molecule M. In addition, the required criteria for successful formation of symmetric and asymmetric proton-bound dimers are determined and discussed. 


\subsection{Instrumentation}

The experiments were performed with an IMS-TOFMS equipped with a corona discharge (CD) ionization source operating in positive mode. The IMS-TOFMS was a homemade instrument constructed in Department of Experimental Physics of Comenius University in Slovakia. A detailed description of the instrument can be found elsewhere [35]. The IMS operated at subambient pressure ( 0.75 bar) so that the sample could be sucked into the ionization region with adjustable flow rate of $20 \mathrm{ml} / \mathrm{min}$. The flow rate of the drift gas was $500 \mathrm{ml} / \mathrm{min}$. The drift tube temperature was set to $110^{\circ} \mathrm{C}$. A voltage of $8 \mathrm{kV}$ was applied to the whole cell of IMS $(12.5 \mathrm{~cm})$ to provide a drift field of $640 \mathrm{~V} / \mathrm{cm}$. The CD was supplied by potential difference of $3 \mathrm{kV}$ between the electrodes. The length of the linear time-of-flight mass spectrometer (TOF-MS) was $54.7 \mathrm{~cm}$ with internal pressure of $10^{-5}$ mbar. A multichannel plate (MCP) was used as a detector for TOFMS.

\subsection{Materials and method}

Pyridine, 2,6-dimethyl pyridine, 2,6-di-tertbuthyl pyridine (DTBP), and ammonium carbonate were Sigma-Aldrich products and acetone, formic acid, formaldehyde, ethanol, 2-butanone, 2octanone, 2-nonanoe, and acetophenone were purchased from Fluka. The head space vapor of each sample at ambient temperature $\left(\sim 20^{\circ} \mathrm{C}\right)$ was injected to the ionization region by a syringe. The

head space vapor of ammonium carbonate, $\left(\mathrm{NH}_{4}\right)_{2} \mathrm{CO}_{3}$, was injected to the ionization region to study ionization and hydration of $\mathrm{NH}_{3}$. The experiments were carried out at drift tube temperature of $110^{\circ} \mathrm{C}$.

\subsection{Computational details}

The structures of all molecules and clusters including neutral and protonated molecules and their hydrated forms were optimized by density functional theory (DFT) and B3LYP functional. The 6- 
$311++\mathrm{G}(\mathrm{d}, \mathrm{p})$ basis which includes both polarization and diffuse functions for hydrogen and heavy atoms was used for the calculations. Frequency calculations were performed at the same level of theory to obtain the thermodynamic quantities including proton affinities (PA), enthalpy $(\Delta \mathrm{H})$ and Gibbs free energy $(\Delta G)$ of hydration or cluster formation. The charge distributions were computed using natural bond orbital (NBO) method. The calculations were carried out at $298.15 \mathrm{~K}$ and in gas phase using Gaussian 09 software [36].

\section{Results and discussion}

\subsection{Effect of basicity on the hydration and proton-bound dimer formation}

Figure 1 shows the mass spectra of formaldehyde, acetone, 2-butanone, 2-octanone, 2-nonanoe, acetophenone, pyridine, 2,6-dimethyl pyridine (DMP), and 2,6-di-tertbutyl pyridine (DTBP). Amount of hydration and cluster formation decrease from formaldehyde to DTBP. Formaldehyde and acetone form clusters with up to three $\mathrm{H}_{2} \mathrm{O}$ molecules; the protonated butanone is di-hydrated; other larger ketones and pyridine and DMP are only mono-hydrated while DTBP is not hydrated. Also, we observed a proton-bound trimer $\left(\mathrm{M}_{3} \mathrm{H}^{+}\right)$peak for formaldehyde, a proton-bound dimer $\left(\mathrm{MH}^{+} \mathrm{M}\right)$ for ketones while DMP and DTBP do not form any dimer or trimer. Since the water concentration and drift cell temperature were the same for the all experiments, the difference in the amount of hydration is attributed to the basicity of the molecules. The calculated values of proton affinities (PA) and gas phase basicities (GB) are summarized in Table 1. The calculated enthalpies $(\Delta \mathrm{H})$ and Gibbs free energies $(\Delta \mathrm{G})$ of mono-hydration and proton-bound dimer formation are also included in Table 1 . The $\Delta \mathrm{H}$ and $\Delta \mathrm{G}$ values for di-, tri- and tetra-hydration as well as trimer formation have been provided in Tables S1 and S2 (Supplementary Materials). The data in Table 1 show that the basicity increases from formaldehyde to DTBP while $\Delta \mathrm{H}$ and $\Delta \mathrm{G}$ 
values of hydration and dimer formation decrease. In other words, the protonated forms $\left(\mathrm{MH}^{+}\right)$of molecules with higher basicity are less hydrated.
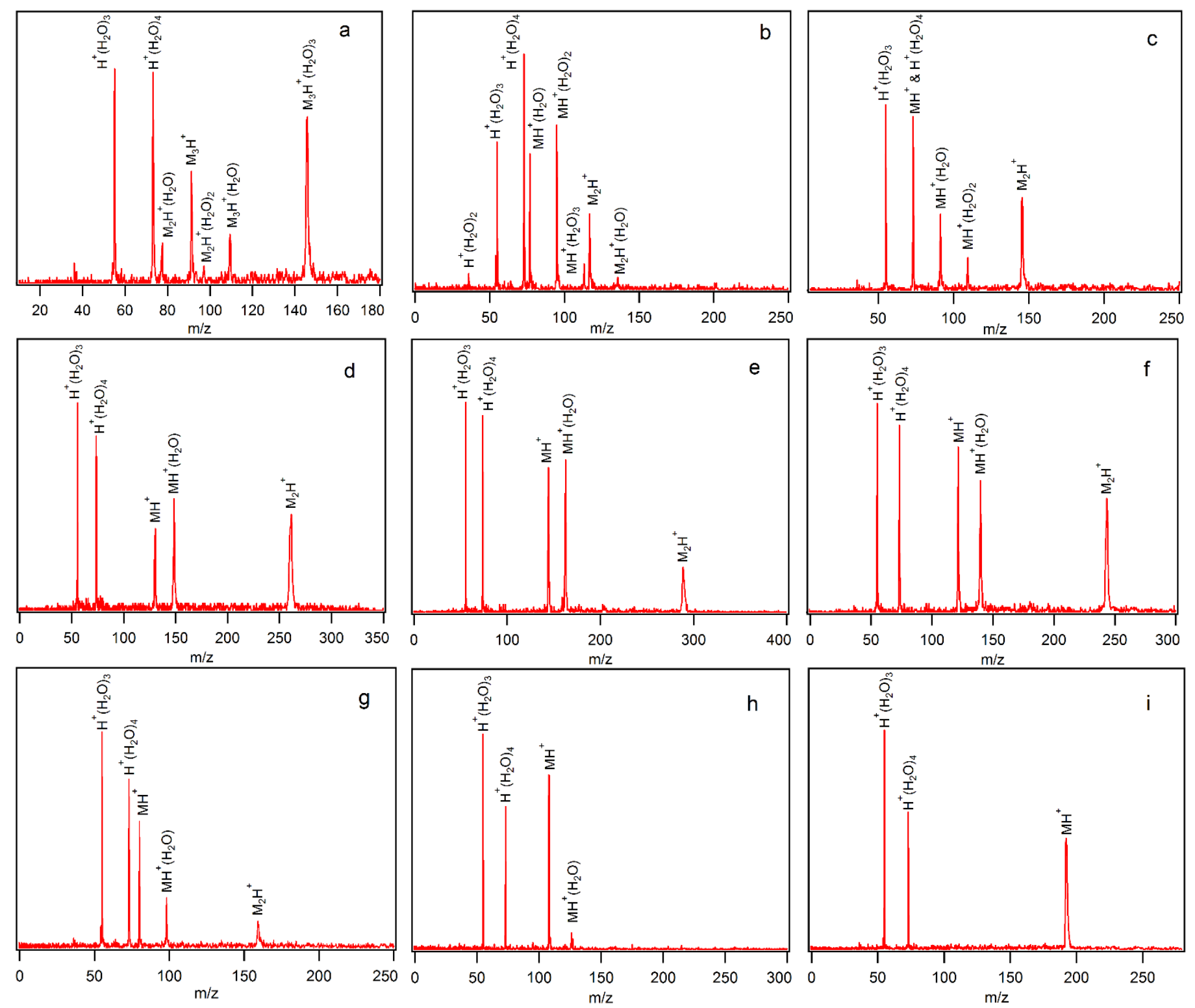

Figure 1. The MS spectra of (a) formaldehyde, (b) acetone, (c) 2-butanone, (d) 2-octanone, (e) 2nonanone, (f) acetophenone, (g) pyridine, (h) 2,6-dimetyl pyridine, and (i) 2,6-di-tert-butyl pyridine. The basicity increases from (a) to (i). 
Table 1 The calculated values of proton affinities (PA), gas phase basicities $(\mathrm{GB})$, enthalpies $(\Delta \mathrm{H})$ and Gibbs free energies $(\Delta G)$ of mono-hydration and proton-bound dimer formation. The energies are in $\mathrm{kJ} / \mathrm{mol}$

\begin{tabular}{|c|c|c|c|c|c|c|}
\hline \multirow[b]{2}{*}{ Molecule (M) } & \multicolumn{2}{|c|}{ Basicity } & \multicolumn{2}{|c|}{ Hydration of $\mathrm{MH}^{+}$} & \multicolumn{2}{|c|}{ Dimer formation } \\
\hline & PA & GB & $\Delta \mathrm{H}$ & $\Delta G$ & $\Delta \mathrm{H}$ & $\Delta \mathrm{G}$ \\
\hline $\mathrm{H}_{2} \mathrm{O}$ & $687.8(691)^{\mathrm{a}}$ & $\begin{array}{l}659.5 \\
(660)^{\mathrm{a}}\end{array}$ & $\begin{array}{l}-154.8 \\
\end{array}$ & -116.7 & -154.8 & -116.7 \\
\hline Formaldehyde & $705.1(712)^{\mathrm{a}}$ & $\begin{array}{c}673.7 \\
(683.3)^{\mathrm{a}}\end{array}$ & -134.4 & -95.7 & -136.1 & -96.3 \\
\hline Formic acid & $\begin{array}{c}740.8 \\
(743.9)^{\mathrm{b}}\end{array}$ & $\begin{array}{c}709.1 \\
(710.3)^{\mathrm{a}}\end{array}$ & -113.8 & -77.6 & -129.7 & -91.3 \\
\hline Ethanol & $\begin{array}{c}779.2 \\
(776.4)^{\mathrm{a}}\end{array}$ & $\begin{array}{l}748.9 \\
(746)^{\mathrm{a}}\end{array}$ & -108.2 & -71.1 & -136.9 & -99.2 \\
\hline Acetone & $816.2(812)^{\mathrm{a}}$ & $\begin{array}{c}784.8 \\
(782.1)^{\mathrm{a}}\end{array}$ & -91.9 & -56.6 & -129.8 & -96.9 \\
\hline 2-Butanone & $\begin{array}{c}831.1 \\
(827.3)^{\mathrm{a}}\end{array}$ & $\begin{array}{c}797.7 \\
(795.5)^{\mathrm{a}}\end{array}$ & -85.6 & -47.2 & -126.4 & -84.0 \\
\hline 2-Ocatnone & 840.9 & 814.8 & -74.1 & -35.9 & -112.4 & -72.3 \\
\hline 2-Nonanone & 841.5 & 815.8 & -74.0 & -35.4 & -112.5 & -69.7 \\
\hline $\mathrm{NH}_{3}$ & $\begin{array}{c}852.7 \\
(853.6)^{\mathrm{a}}\end{array}$ & $\begin{array}{c}824.5 \\
(819.0)^{\mathrm{a}}\end{array}$ & -89.5 & -50.1 & -118.9 & -78.1 \\
\hline Acetophenone & $\begin{array}{c}869.3 \\
(861.1)^{\mathrm{a}}\end{array}$ & $\begin{array}{c}838.8 \\
(829.3)^{\mathrm{a}}\end{array}$ & -76.6 & -37.6 & -117.5 & -75.4 \\
\hline Pyridine & $934.4(930)^{\mathrm{a}}$ & $\begin{array}{c}902.5 \\
(898.1)^{\mathrm{a}}\end{array}$ & -66.5 & -31.8 & -102.3 & -62.2 \\
\hline $\begin{array}{l}\text { 2,6-Dimethyl } \\
\text { pyridine }\end{array}$ & $968.9(963)^{\mathrm{a}}$ & $\begin{array}{c}947.0 \\
(931.1)^{\mathrm{a}}\end{array}$ & -54.37 & -8.3 & -75.8 & -23.4 \\
\hline $\begin{array}{c}\text { 2,6-Di-t-buthyl } \\
\text { pyridine }\end{array}$ & $\begin{array}{c}990.8 \\
(982.9)^{\mathrm{a}} \\
\end{array}$ & $\begin{array}{l}959.7 \\
(951)^{\mathrm{a}} \\
\end{array}$ & -30.2 & +7.8 & -6.3 & +19.9 \\
\hline
\end{tabular}

${ }^{\mathrm{a}}$ Ref.[37] ${ }^{\mathrm{b}}$ calculated by W1BD from Ref [38].

Figure 2 shows the optimized structures of the clusters observed in the MS spectra of Fig. 1. Comparison of the $\mathrm{MH}^{+} \ldots \mathrm{OH}_{2}$ bond lengths reveals that this distance is shorter for molecules (M) with lower basicity and longer for molecules with higher basicity which is in agreement with hydration enthalpies. The same trend is observed for the bond lengths in the proton-bound dimers, $\mathrm{MH}^{+} \ldots \mathrm{M}$. The relationship between basicity of $\mathrm{M}$ and $\mathrm{MH}^{+} \ldots \mathrm{M}$ distance has been recently predicted theoretically [39]. Figure S1 (Supplementary Materials) shows the variations of $\mathrm{MH}^{+} \ldots \mathrm{OH}_{2}$ and $\mathrm{MH}^{+} \ldots \mathrm{M}$ distances versus $\mathrm{PA}$ of $\mathrm{M}$. These plots show that there is a linear 
relationship between these hydrogen bond distances and PA so that as PA increases the hydrogen bonds are lengthened. The more basic molecules has more ability to delocalize the positive charge of the entering proton, therefore, it is expected that the partial charge on the proton in $\mathrm{MH}^{+}$is smaller for more basic molecules. Figure S2 (Supplementary Materials) shows the NBO charge distributions for the protonated molecules studied in this work. As PA of M increases the main part of the positive charge of $\mathrm{H}^{+}$is transferred to $\mathrm{M}$ so that the partial charge (q) on the $\mathrm{H}$ atom of $\mathrm{MH}^{+}$decreases. Hence, the $\mathrm{MH}^{+} / \mathrm{H}_{2} \mathrm{O}$ or $\mathrm{MH}^{+} / \mathrm{M}$ interactions become weaker and the $\Delta \mathrm{H}$ values of hydration or dimer formation decrease.

Some part of low tendency of DTBPH ${ }^{+}$to hydration or dimer formation is due to steric hindrance of bulky butyl groups adjacent to the proton acceptor site, $\mathrm{N}$. To investigate this effect, hydration enthalpy of a molecule with strong basicity $(\mathrm{PA}=1020 \mathrm{~kJ} / \mathrm{mol})[40]$ without any steric hindrance was calculated (Fig. S3 in Supplementary Materials). The calculated hydration enthalpy for this molecule is $-50 \mathrm{~kJ} / \mathrm{mol}$ which is smaller than those for all molecules studied in this work except DTBP. Therefore, although steric hindrance may influence the hydration enthalpy, basicity has a determinant effect on the hydration. 

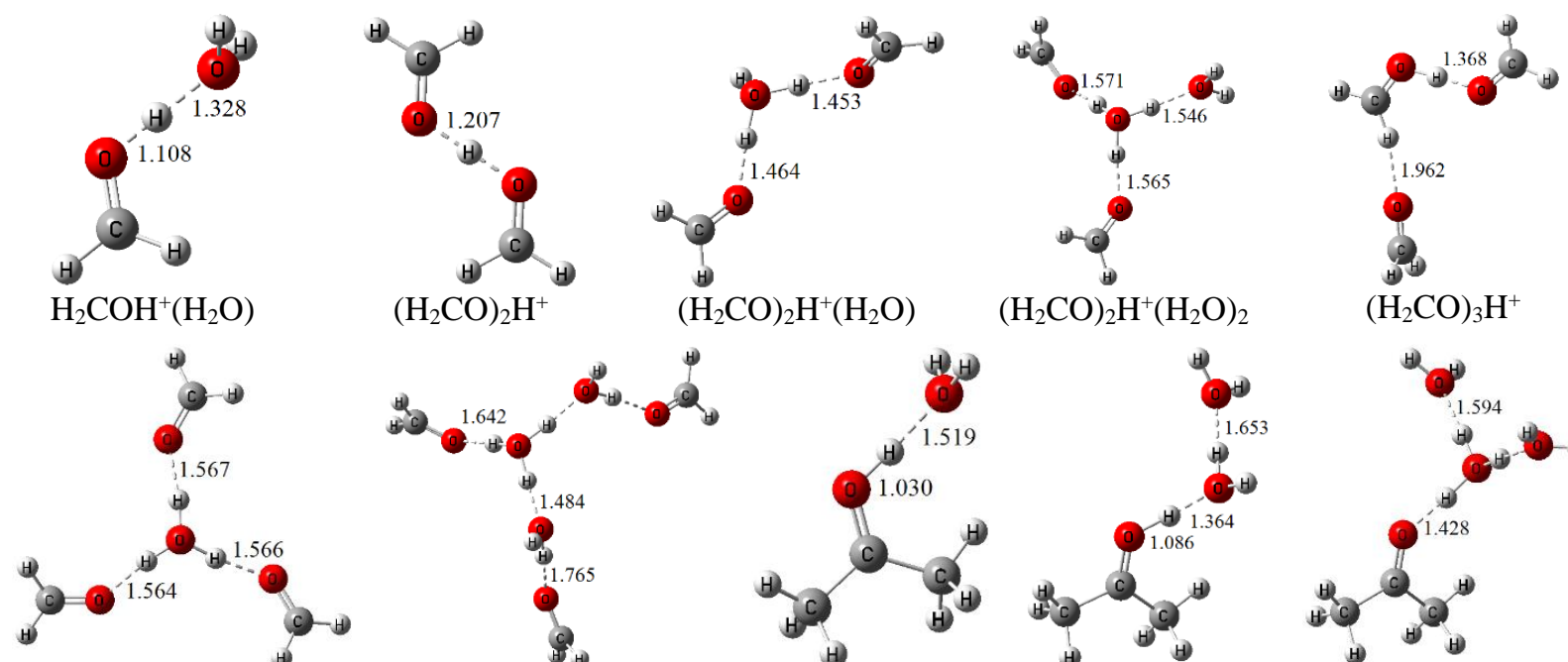

$\left(\mathrm{H}_{2} \mathrm{CO}\right)_{2} \mathrm{H}^{+}\left(\mathrm{H}_{2} \mathrm{O}\right)$

$\left(\mathrm{H}_{2} \mathrm{CO}\right)_{2} \mathrm{H}^{+}\left(\mathrm{H}_{2} \mathrm{O}\right)_{2}$

$\left(\mathrm{H}_{2} \mathrm{CO}\right)_{3} \mathrm{H}^{+}$$$
\text { 类 } 1.642 \text { (1) }
$$
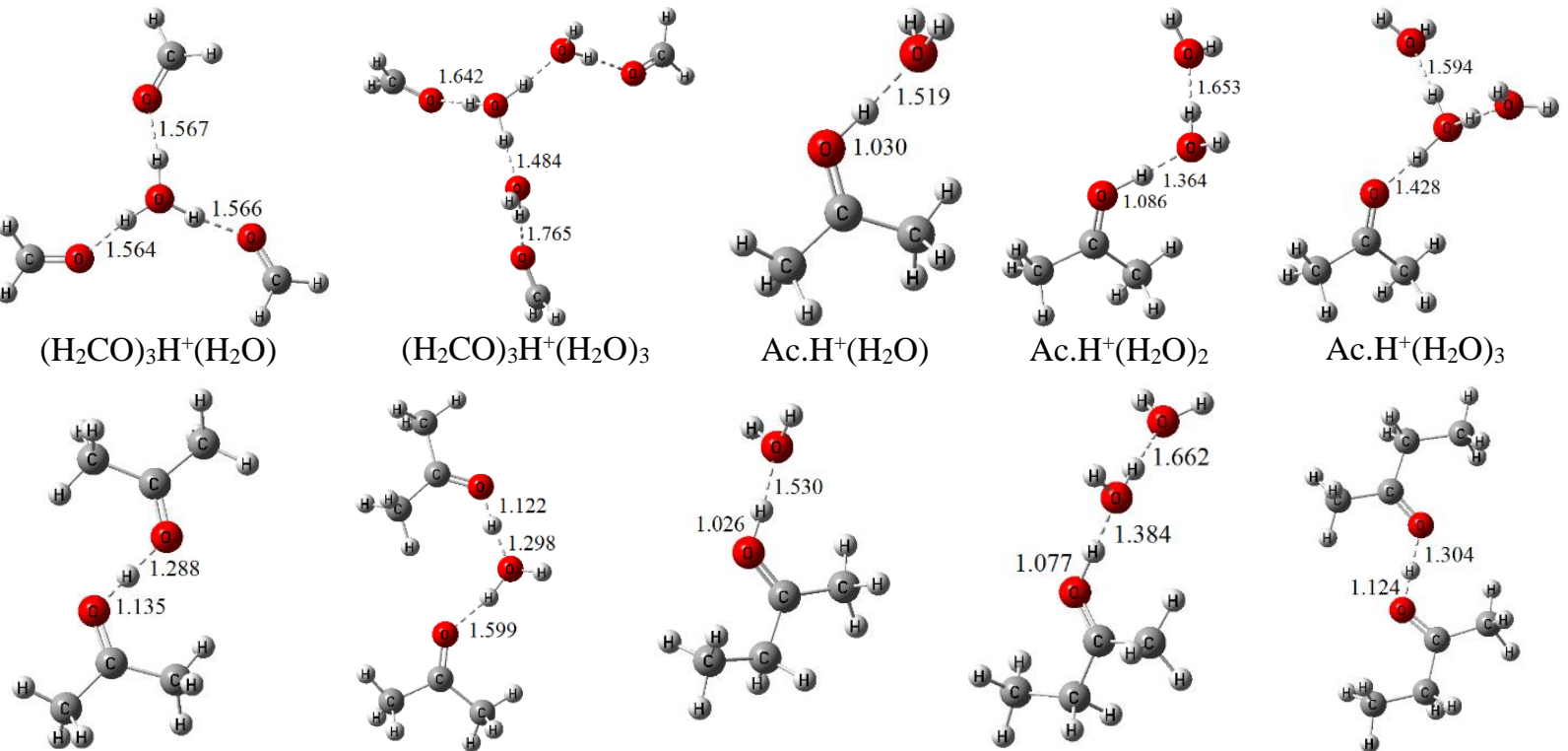

$$
(\mathrm{Ac})_{2} \mathrm{H}^{+}\left(\mathrm{H}_{2} \mathrm{O}\right)
$$

$(\mathrm{Ac})_{2} \mathrm{H}^{+}\left(\mathrm{H}_{2} \mathrm{O}\right)$
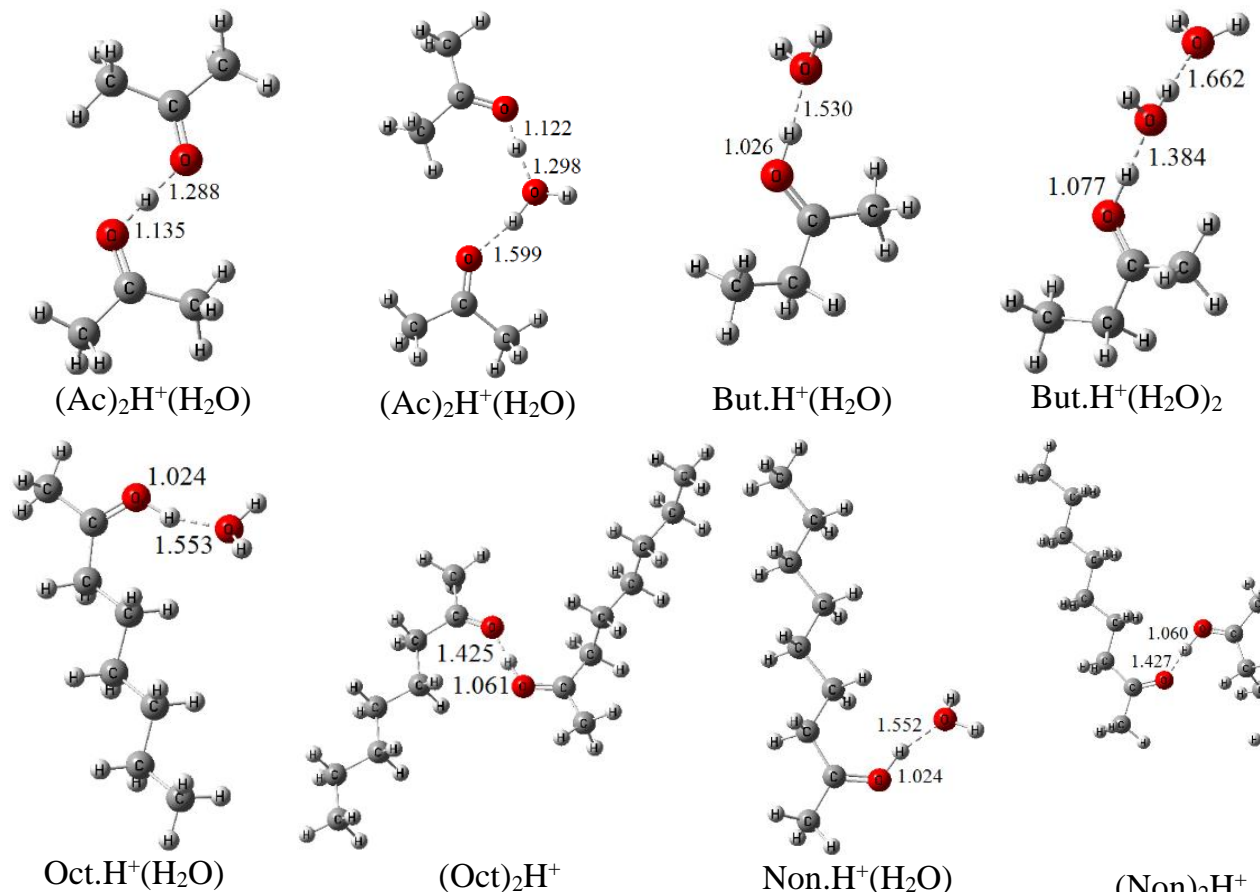

But. $\mathrm{H}^{+}\left(\mathrm{H}_{2} \mathrm{O}\right)_{2}$

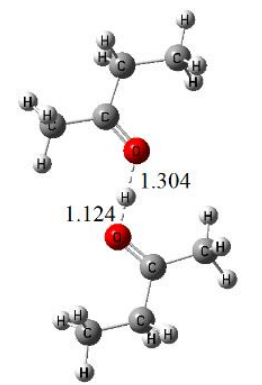

(But) $)_{2} \mathrm{H}^{+}$
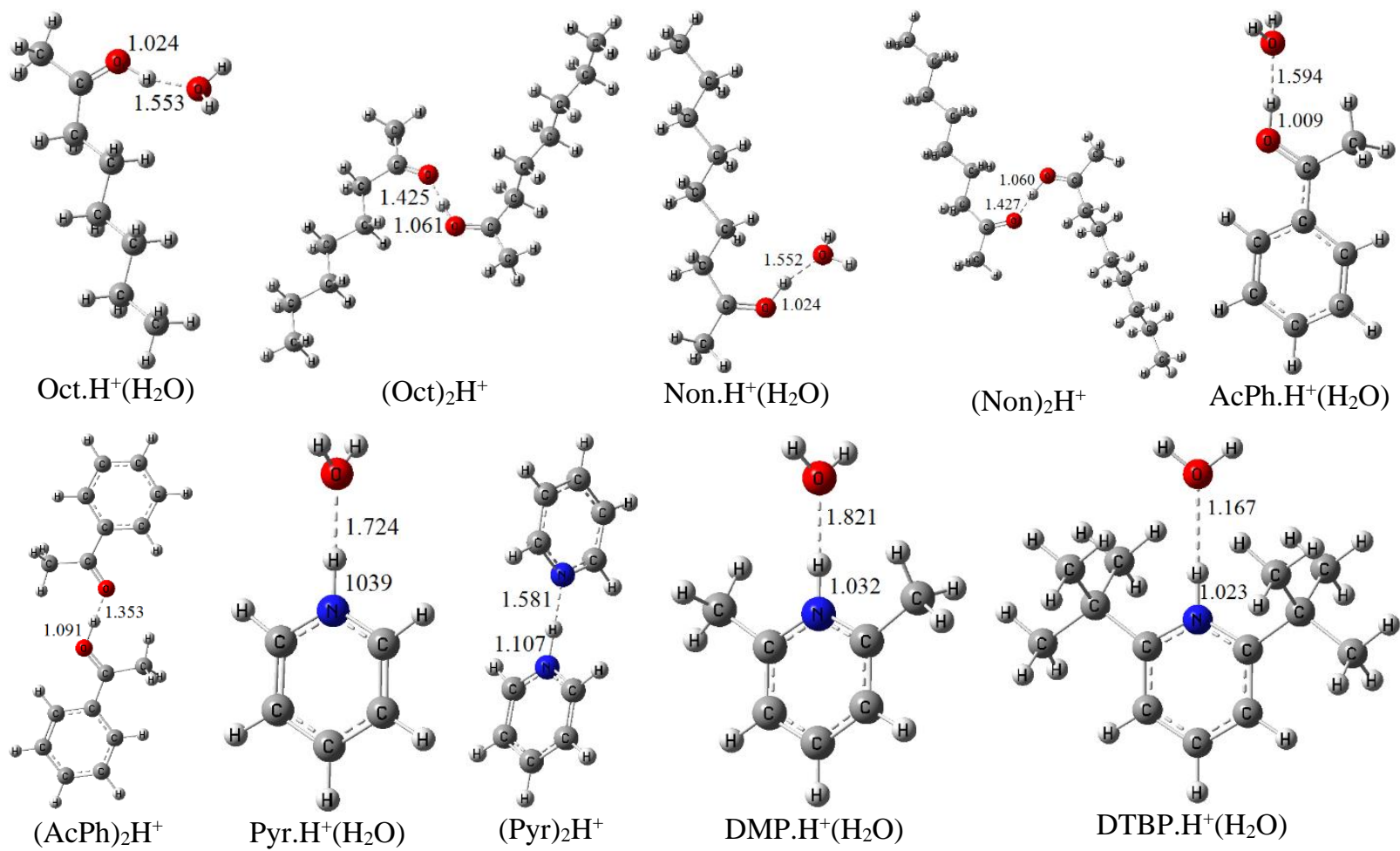

Non. $\mathrm{H}^{+}\left(\mathrm{H}_{2} \mathrm{O}\right)$

(Non) ${ }_{2} \mathrm{H}^{+}$ AcPh. $\mathrm{H}^{+}\left(\mathrm{H}_{2} \mathrm{O}\right)$
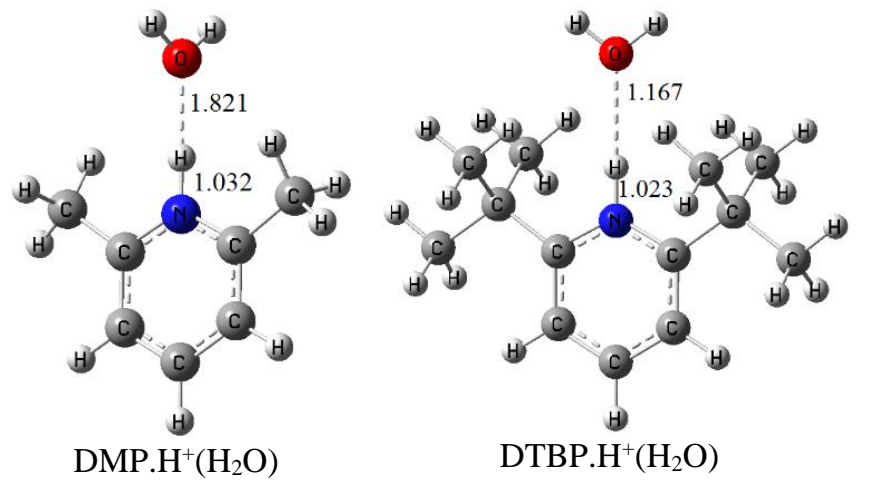
Figure 2. The optimized structures of the clusters observed in the MS spectra of Fig. 1. The bond lengths are in Å. Ac: Acetone; But: 2-Butanone; Oct: 2-Octanone; Non: 2-Nonanone; AcPh: Acetophenone; Pyr: Pyridine; DMP: 2,6-Dimethyl pyridine; DTBP: Di-tertbutyl pyridine

It has been reported that moisture can destroy the proton-bound dimers or proton-bound dimers are rarely hydrated $[25,30,31]$. Comparison of the enthalpies of hydration and dimer formation (Table 1) shows that formation of proton-bound dimers from $\mathrm{MH}^{+}$and $\mathrm{M}$ is thermodynamically more favorable than hydration of $\mathrm{MH}^{+}$. However, in the presence of high amount of water vapor, according to the Le Chatelier's principle, the reaction $\mathrm{M}_{2} \mathrm{H}^{+}+\mathrm{H}_{2} \mathrm{O} \rightarrow \mathrm{MH}^{+}\left(\mathrm{H}_{2} \mathrm{O}\right)+\mathrm{M}$ may be occurred resulting in dimer destruction. Hydration of proton-bound dimers depends on the structures of $\mathrm{M}$ and $\mathrm{MH}^{+}$which is discussed in the next section.

\subsection{Effect of size and structure on the hydration and proton-bound dimer formation}

Other than basicity, size and structure of a molecule affect its hydration and cluster formation enthalpies. Figure $3 \mathrm{a}$ and $3 \mathrm{~b}$ compares the $\mathrm{MS}$ spectra of $\mathrm{NH}_{3}$ and $\mathrm{H}_{2} \mathrm{O}$ with PA difference of about $60 \mathrm{~kJ} / \mathrm{mol}$. Hydration of ammonium ion proceeds to tri-hydration, $\mathrm{NH}_{4}{ }^{+}\left(\mathrm{H}_{2} \mathrm{O}\right)_{3}$, while octanone- $\mathrm{H}^{+}$, nonanone- $\mathrm{H}^{+}$, and acetophenone- $\mathrm{H}^{+}$with comparable PA are mono-hydrated in the same condition. $\mathrm{H}_{3} \mathrm{O}^{+}$and $\mathrm{NH}_{4}{ }^{+}$are small ions with comparable size, therefore, we can attribute their large amount of hydrations to their large surface density of the positive charge leading in strong interactions with water molecules. However, comparison of the hydration enthalpies of $\mathrm{H}_{3} \mathrm{O}^{+}$and $\mathrm{NH}_{4}{ }^{+}$(Table S1) shows that hydration enthalpies of $\mathrm{NH}_{4}{ }^{+}$are noticeably smaller than those of $\mathrm{H}_{3} \mathrm{O}^{+}$. Another factor influencing the hydration of $\mathrm{NH}_{4}{ }^{+}$is four identical hydrogen atoms which can participate in hydrogen bonding interactions with water molecules (Fig. S4 in Supplementary Materials). 

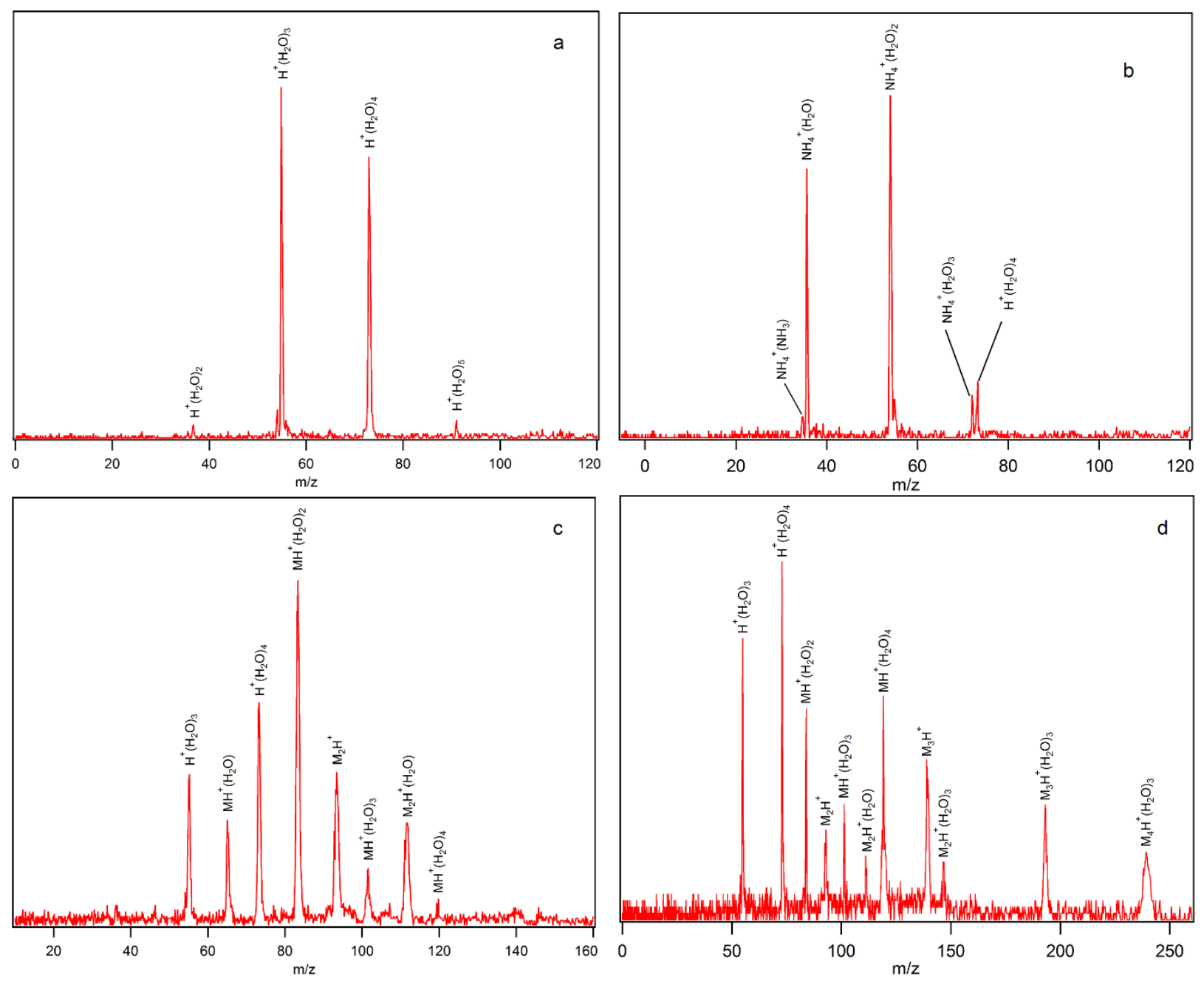

Figure 3. MS spectra for (a) water clusters, (b) hydrated ammonium, (c) ethanol, and (d) formic acid

To investigate effect of structure in more details, hydration and clustering of ethanol and formic acid with the same molecular weights, comparable PAs, and different structures were studied. Figures $3 \mathrm{c}$ and $3 \mathrm{~d}$ compare the $\mathrm{MS}$ spectra of ethanol and formic acid. Both $\mathrm{C}_{2} \mathrm{H}_{5} \mathrm{OH}_{2}{ }^{+}$and $\mathrm{HC}(\mathrm{OH})_{2}{ }^{+}$, the protonated forms of ethanol and formic acid, have two hydrogen atoms which can participate in hydration or cluster formation. However, Fig. 3 exhibits two different patterns of hydration and clustering for ethanol and formic acid. $\mathrm{C}_{2} \mathrm{H}_{5} \mathrm{OH}_{2}{ }^{+}$mainly participates in hydration 
reactions while $\mathrm{HC}(\mathrm{OH})_{2}{ }^{+}$tends to be both hydrated and clustered. The optimized structures of different clusters of ethanol and formic acid have been provided in Supplementary Materials (Figs. $\mathrm{S} 5, \mathrm{~S} 6$ and $\mathrm{S7}$ ). Neutral formic acid, $\mathrm{HC}=\mathrm{O}(\mathrm{OH})$, has a carbonyl groups, $\mathrm{C}=\mathrm{O}$, whose oxygen atom acts as a hydrogen bond acceptor without any steric hindrance while, at the same time, the $\mathrm{OH}$ group is involved in another hydrogen bonding interaction. Therefore, each formic acid molecule plays the role of a ring of a chain in a hydrogen bonding network (Fig S7). On the other hand, ethanol, $\mathrm{C}_{2} \mathrm{H}_{5} \mathrm{OH}$ has only one $\mathrm{OH}$ group; when it interacts via its $\mathrm{H}$ atom, the $\mathrm{O}$ atom cannot freely form another hydrogen bond with other molecules. It should be mentioned that the more tendency of formic acid to be clustered compared to ethanol is not due to higher concentration of formic acid in the ionization region because we injected the head space vapor of the compounds and vapor pressure of ethanol is more than that of formic acid.

Figure 1 shows that, similar to formic acid, aldehyde also forms a proton-bound trimer, $\left(\mathrm{H}_{2} \mathrm{CO}\right)_{3} \mathrm{H}^{+}$. Because of small size of formaldehyde and the high charge density of its protonated form, $\mathrm{H}_{2} \mathrm{C}=\mathrm{OH}^{+}$, the hydrogen of $\mathrm{CH}$ group also participates in cluster formation (Fig. 2). Another reason for formation of formaldehyde trimer is its higher concentration in the ionization region due to its high vapor pressure. However, enthalpy of trimer formation, $\mathrm{M}_{2} \mathrm{H}^{+}+\mathrm{M} \rightarrow \mathrm{M}_{3} \mathrm{H}^{+}$, for formaldehyde is about $23 \mathrm{~kJ} / \mathrm{mol}$ smaller than that for formic acid (Table S2 in Supplementary Materials). $\mathrm{H}_{2} \mathrm{O}$ molecules can act as bridges between the formaldehyde molecules and form more stable cluster of $\left(\mathrm{H}_{2} \mathrm{CO}\right)_{3} \mathrm{H}^{+}\left(\mathrm{H}_{2} \mathrm{O}\right)_{3}$ whose peak is more intense than the $\left(\mathrm{H}_{2} \mathrm{CO}\right)_{3} \mathrm{H}^{+}$peak (Fig. 1a). However, in the case of formic acid the $(\mathrm{HCOOH})_{3} \mathrm{H}^{+}$peak is more intense compared to the $(\mathrm{HCOOH})_{3} \mathrm{H}^{+}\left(\mathrm{H}_{2} \mathrm{O}\right)_{3}$ peak. Comparison of the formation enthalpies in Tables $\mathrm{S} 2$ and $\mathrm{S} 3$ shows that although $(\mathrm{HCOOH})_{3} \mathrm{H}^{+}$is more stable than $\left(\mathrm{H}_{2} \mathrm{CO}\right)_{3} \mathrm{H}^{+}$, the stability for the tri-hydrated clusters is reverse so that $\left(\mathrm{H}_{2} \mathrm{CO}\right)_{3} \mathrm{H}^{+}\left(\mathrm{H}_{2} \mathrm{O}\right)_{3}$ is more stable than $(\mathrm{HCOOH})_{3} \mathrm{H}^{+}\left(\mathrm{H}_{2} \mathrm{O}\right)_{3}$. This 
observation reveals that the structure of formic acid with both hydrogen bond donor and acceptor sites compared to formaldehyde with only one proton bond acceptor site is more capable for clustering so that the formic acid forms more stable trimers without any water bridge. The structures of $\left(\mathrm{H}_{2} \mathrm{CO}\right)_{3} \mathrm{H}^{+}\left(\mathrm{H}_{2} \mathrm{O}\right)_{3}$ and $(\mathrm{HCOOH})_{3} \mathrm{H}^{+}\left(\mathrm{H}_{2} \mathrm{O}\right)_{3}$ are shown in Figs. 2 and $\mathrm{S} 7$, respectively. $\left(\mathrm{H}_{2} \mathrm{CO}\right)_{3} \mathrm{H}^{+}\left(\mathrm{H}_{2} \mathrm{O}\right)_{3}$ has only one stable structure while different isomers were predicted for $(\mathrm{HCOOH})_{3} \mathrm{H}^{+}\left(\mathrm{H}_{2} \mathrm{O}\right)_{3}$.

Clustering of formic acid proceeds up to tetramer with three water molecules, $(\mathrm{HCOOH})_{4} \mathrm{H}^{+}\left(\mathrm{H}_{2} \mathrm{O}\right)_{3}$. The eight possible structures for the $(\mathrm{HCOOH})_{4} \mathrm{H}^{+}\left(\mathrm{H}_{2} \mathrm{O}\right)_{3}$ are shown in Fig. 4. Comparison of the relative stabilities of the $(\mathrm{HCOOH})_{3} \mathrm{H}^{+}\left(\mathrm{H}_{2} \mathrm{O}\right)_{3}$ (Fig. S7) and $(\mathrm{HCOOH})_{4} \mathrm{H}^{+}\left(\mathrm{H}_{2} \mathrm{O}\right)_{3}$ isomers (Fig. 4) shows that the structures in which the proton remains on the water and $\mathrm{H}_{3} \mathrm{O}^{+}$is the core center of the cluster are more stable. These results are in accordance with those previously reported [14-16]. The isomers a and $\mathbf{b}$ of $(\mathrm{HCOOH})_{4} \mathrm{H}^{+}\left(\mathrm{H}_{2} \mathrm{O}\right)_{3}$ in which the water and formic acid molecules have been positioned alternatively, are the less stable structures. The isomers $\mathbf{c}$ and $\mathbf{f}$ with a water cluster of $\mathrm{H}_{3} \mathrm{O}^{+}\left(\mathrm{H}_{2} \mathrm{O}\right)_{2}$ are the most stable structures, however, the isomer $\mathbf{c}$ in which the $\mathrm{H}_{3} \mathrm{O}^{+}\left(\mathrm{H}_{2} \mathrm{O}\right)_{2}$ group is located in the center of the $(\mathrm{HCOOH})_{4} \mathrm{H}^{+}\left(\mathrm{H}_{2} \mathrm{O}\right)_{3}$ is more stable. 


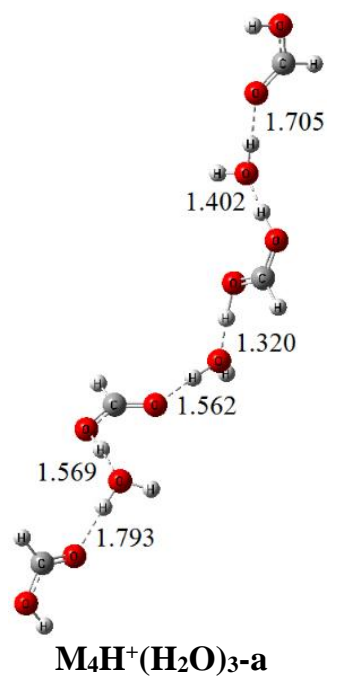

17.3

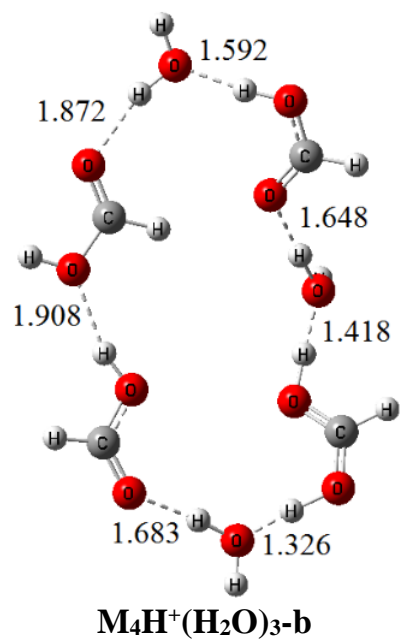

25.9

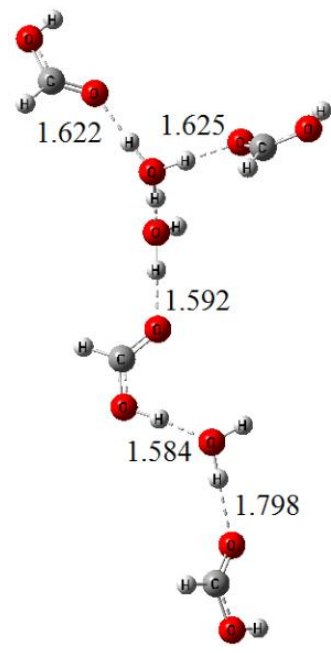

$\mathrm{M}_{4} \mathrm{H}^{+}\left(\mathrm{H}_{2} \mathrm{O}\right)_{3}-\mathrm{e}$

10.6

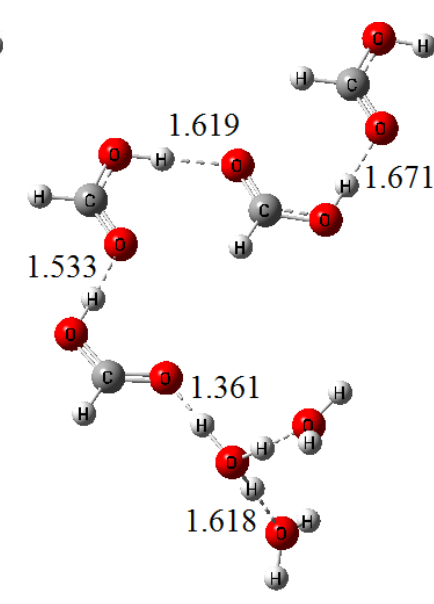

$\mathbf{M}_{4} \mathbf{H}^{+}\left(\mathbf{H}_{2} \mathbf{O}\right)_{3}-\mathbf{f}$
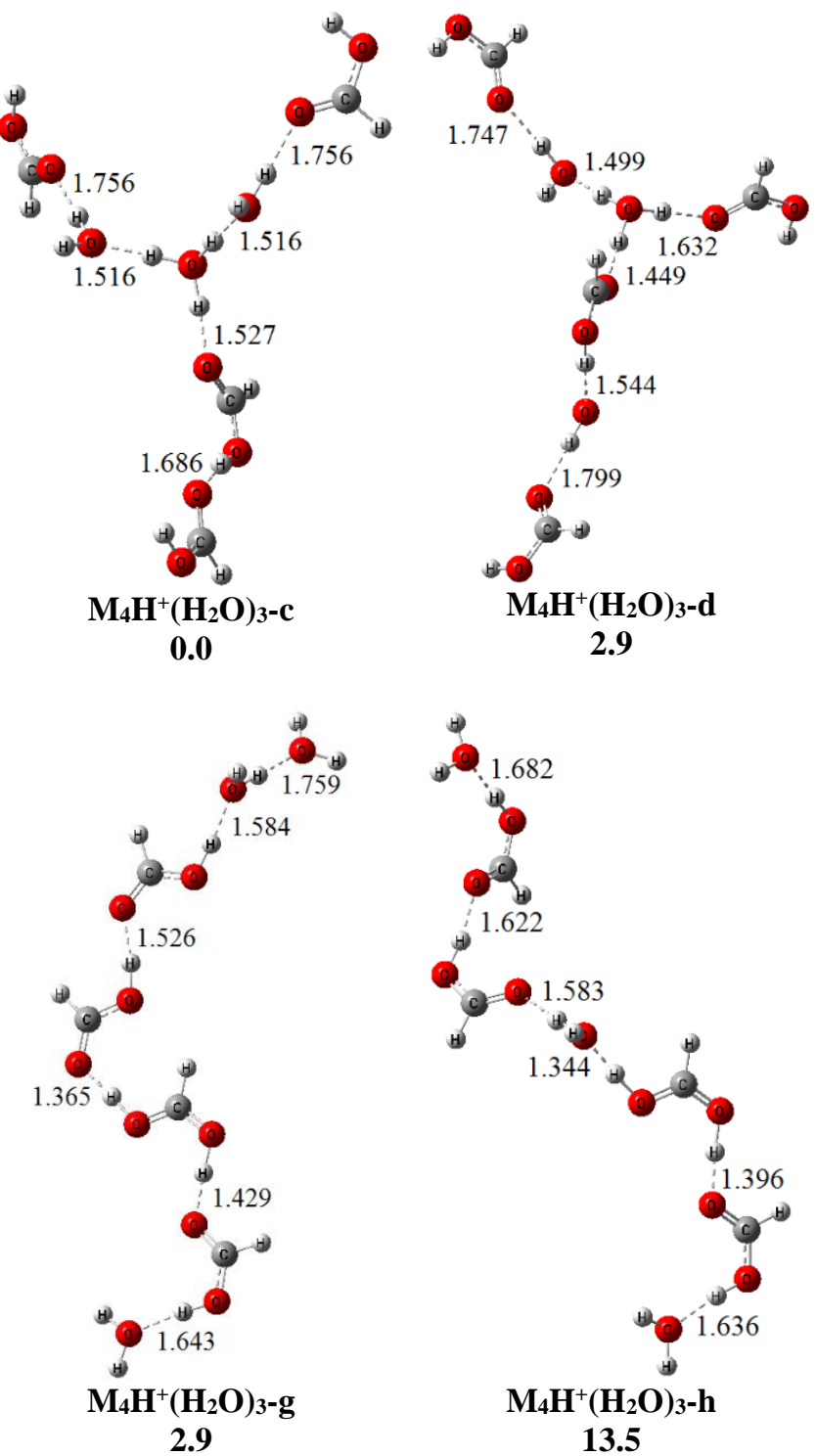

Figure 4. The optimized structures of different isomers of $(\mathrm{HCOOH})_{4} \mathrm{H}^{+}\left(\mathrm{H}_{2} \mathrm{O}\right)_{3}$ cluster. The relative energies and bond lengths are in $\mathrm{kJ} / \mathrm{mol}$ and $\AA$, respectively

\subsection{Effect of basicity on the asymmetric proton-bound dimer formation}

The MS spectra of Figs. 1 and 3 show that although the chance of formation of the symmetric proton-bound dimers $\left(\mathrm{MH}^{+} \mathrm{M}\right)$ decreases with increase in the basicity of the molecule $\mathrm{M}$, these symmetric dimers are readily formed. Figures 5a compares the IMS spectra of 2-octanone, acetophenone and their mixtures. The IMS spectra of 2-octanone and acetophenone show only the monomer, $\left(\mathrm{MH}^{+}\right)$and dimer $\left(\mathrm{MH}^{+} \mathrm{M}\right)$ peaks of these molecules. In the IMS spectrum of their 
mixture a new peak with high intensity appears between the symmetric dimers. The MS spectrum of this mixture (Fig. 5b) confirms that the new peak is due to formation of the asymmetric dimer of octanone- $\mathrm{H}^{+}$-acetophenone. When a mixture of pyridine and 2-octanone was injected into IMS, a small peak was hardly observed between the dimer peaks of pyridine and 2-octanone (Fig. 5c). The experiment was repeated with several mixtures with different ratios of 2-octanone/pyridine. The MS spectrum of the octanone/pyridine mixture shows that the new peak is due to the asymmetric dimer of octanone- $\mathrm{H}^{+}-$pyridine (Fig. 5d).
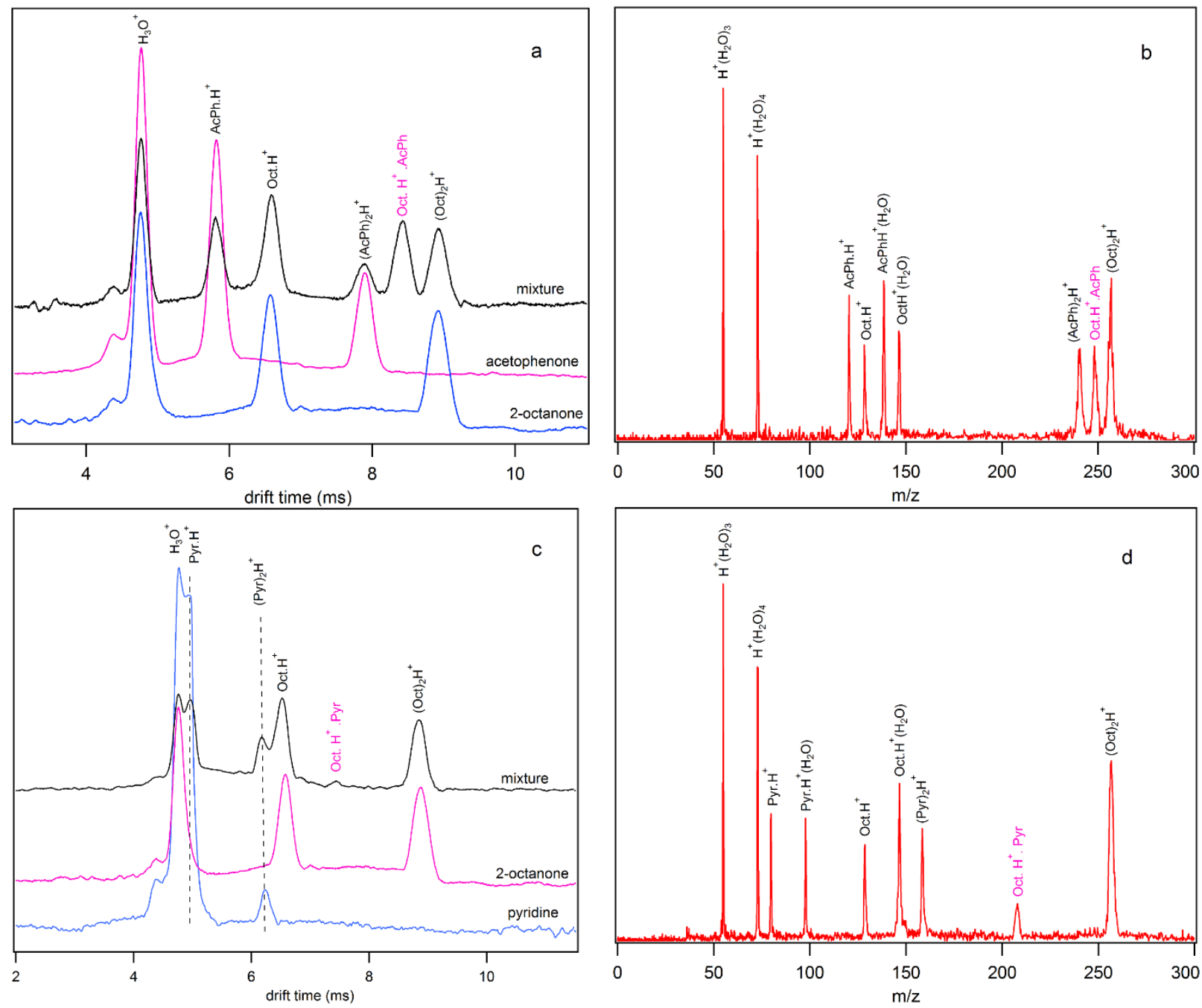

Figure 5. (a) IMS spectra for 2-octanone, acetophenone, and their mixture; (b) MS spectrum for 2-ocatnone/acetophenone mixture; (c) IMS spectra for 2-octanone, pyridine, and their mixture; and (d) MS spectrum of the 2-octanone/pyridine mixture. The peaks of the asymmetric proton- 
bound dimers have been shown by purple color. Oct: 2-octanone; AcPh: acetophenone; Pyr: pyridine

The calculated values of $\Delta \mathrm{H}$ and $\Delta \mathrm{G}$ for formation of the symmetric $\left(\mathrm{MH}^{+} \mathrm{M}\right)$ and asymmetric dimers $\left(\mathrm{MH}^{+} \mathrm{N}\right)$ are tabulated in Table 2. Furthermore, PA differences $(\Delta \mathrm{PA})$ of the molecules participating in the dimer formation are also included in Table 2. For the symmetric dimer the $\Delta \mathrm{PA}$ values are zero and the enthalpies of dimer formation are about -102 to $-117 \mathrm{~kJ} / \mathrm{mol}$. For the asymmetric dimer octanone- $\mathrm{H}^{+}$-acetophenone, the basicities of octanone and acetophenone are not so different ( $\triangle \mathrm{PA}=28 \mathrm{~kJ} / \mathrm{mol})$, therefore, this asymmetric dimer is easily formed with enthalpy of $-106 \mathrm{~kJ} / \mathrm{mol}$. The difference of basicity between octanone and pyridine is considerable $(\Delta \mathrm{PA}=94$ $\mathrm{kJ} / \mathrm{mol})$ resulting in lower enthalpy of asymmetric dimer formation $(\Delta \mathrm{H}=-85 \mathrm{~kJ} / \mathrm{mol})$. In summary, the asymmetric dimers are formed more easily between the molecules with comparable basicity.

Table 2 The calculated values of $\Delta \mathrm{H}$ and $\Delta \mathrm{G}$ for the symmetric and asymmetric dimer formations

\begin{tabular}{|c|c|c|c|}
\hline Dimer formation $^{\mathrm{a}}$ & $\Delta \mathrm{H}$ & $\Delta \mathrm{G}$ & $\Delta \mathrm{PA}^{\mathrm{b}}$ \\
\hline $\mathrm{Oct}+\mathrm{Oct} \cdot \mathrm{H}^{+} \rightarrow(\mathrm{Oct})_{2} \mathrm{H}^{+}$ & -112.4 & -72.3 & 0.0 \\
\hline $\mathrm{AcPh}+\mathrm{AcPh} \cdot \mathrm{H}^{+} \rightarrow(\mathrm{AcPh})_{2} \mathrm{H}^{+}$ & -117.5 & -75.4 & 0.0 \\
\hline $\mathrm{Pyr}+\mathrm{Pyr} . \mathrm{H}^{+} \rightarrow(\mathrm{Pyr})_{2} \mathrm{H}^{+}$ & -102.3 & -62.2 & 0.0 \\
\hline $\mathrm{Oct}+\mathrm{AcPh} \cdot \mathrm{H}^{+} \rightarrow(\mathrm{Oct}-\mathrm{H}-\mathrm{AcPh})^{+}$ & -106.3 & -69.5 & 28.4 \\
\hline Oct + Pyr.H $H^{+} \rightarrow(\text { Oct-H-Pyr })^{+}$ & -84.7 & -54.5 & 93.5 \\
\hline
\end{tabular}

${ }^{\mathrm{a} O c t:}$ 2-octanone; AcPh: acetophenone; Pyr: pyridine. ${ }^{\mathrm{b}} \Delta \mathrm{PA}\left(\mathrm{MH}^{+} \mathrm{N}\right)=\mathrm{PA}(\mathrm{M})-\mathrm{PA}(\mathrm{N})$ of the molecules participating in dimer formation.

The optimized structures of the studied symmetric and asymmetric proton-bound dimers are compared in Fig 6. The M...H...M and M...H...N hydrogen bond lengths are also shown in $\AA$. In the symmetric dimer of acetophenone, with the highest enthalpy of formation, the bond lengths are 1.353 and $1.091 \AA$ and their difference is $0.262 \AA$. On the other hand, for the asymmetric dimer 
of octanone- $\mathrm{H}^{+}-$pyridine, with the lowest enthalpy of formation, the difference in the bond lengths is $0.601 \AA$. It seems there is a direct relationship between the enthalpy of dimer formation and the structure. The plot of variations of enthalpy of dimer formation versus the difference in the hydrogen bond lengths in the dimer structures is shown in Fig. S8 (Supplementary Materials). Observation of this relationship is expectable because difference in the hydrogen bond lengths is due to difference in the basicities of the molecules participating in proton-bound formation which, as mentioned above, it determines the enthalpy of dimer formation.

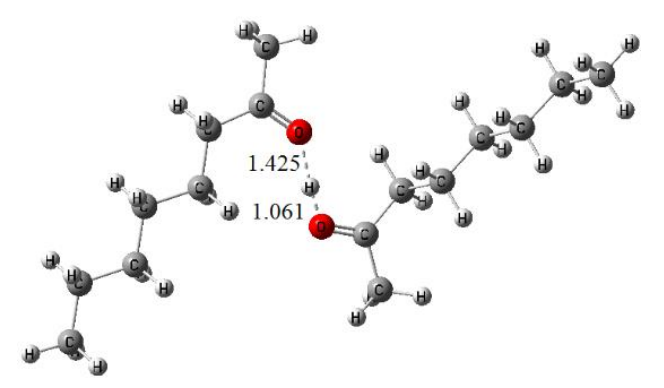

(Octanone $)_{2} \mathrm{H}^{+}$

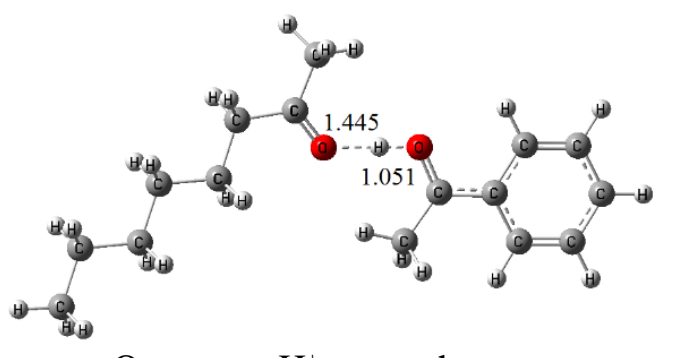

Octanone- $\mathrm{H}^{+}$-acetophenone

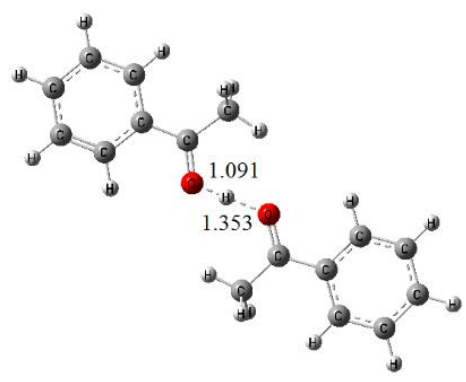

(Acetophenone) ${ }_{2} \mathrm{H}^{+}$

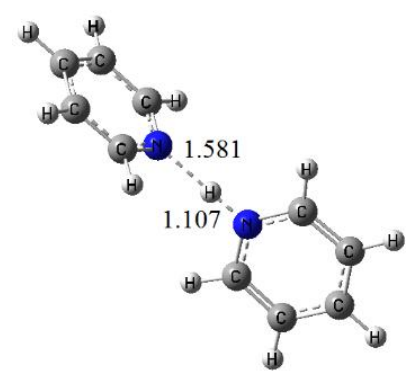

(Pyridine) ${ }_{2} \mathrm{H}^{+}$

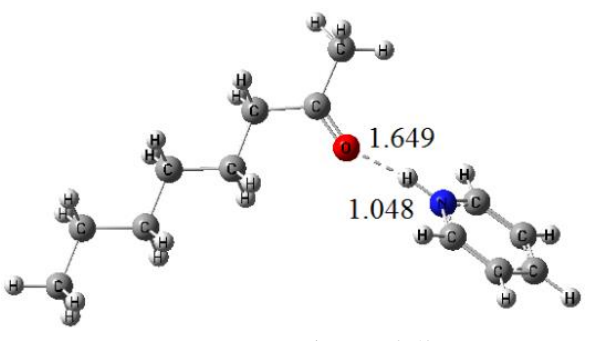

Octanone- $\mathrm{H}^{+}-$pyridine

Figure 6 The optimized structures of the studied symmetric and asymmetric proton-bound dimers. The bond lengths are in $\AA$

\section{Conclusion}

The thermodynamic and structural criteria for cluster formation and hydration of protonated molecules $\left(\mathrm{MH}^{+}\right)$were investigated both experimentally and theoretically. Comparison of the MS spectra of a class of compounds with a wide range of basicity $(\mathrm{PA}=690-990 \mathrm{~kJ} / \mathrm{mol})$ showed that 
amount of hydration of $\mathrm{MH}^{+}$decreases as the $\mathrm{PA}$ of $\mathrm{M}$ increases so that more basic compounds form smaller $\mathrm{MH}^{+}\left(\mathrm{H}_{2} \mathrm{O}\right)_{n}$ clusters. The same trend was observed for formation of proton-bound dimers $\left(\mathrm{M}_{2} \mathrm{H}^{+}\right)$, trimmers $\left(\mathrm{M}_{3} \mathrm{H}^{+}\right)$and tetramers $\left(\mathrm{M}_{4} \mathrm{H}^{+}\right)$so that the tendency of compounds with lower basicity for dimer, trimer or tetramer formation is more. Generally, the protonated form of a more basic molecule tends to form smaller clusters. Structures of $\mathrm{M}$ and $\mathrm{MH}^{+}$also influence the amount of hydration or clustering. Although $\mathrm{NH}_{3}$ has high basicity, its MS spectrum shows that the cluster $\mathrm{NH}_{4}{ }^{+}\left(\mathrm{H}_{2} \mathrm{O}\right)_{3}$ is easily formed because of four identical hydrogen atoms of $\mathrm{NH}_{4}{ }^{+}$acting as hydrogen bond donors. Also, formic acid due to its $\mathrm{C}=\mathrm{O}$ and $\mathrm{OH}$ groups can interact with two hydrogen bond donor and acceptor atoms simultaneously and forms a network or chain cluster. Therefore, despite of its higher basicity compared to $\mathrm{H}_{2} \mathrm{O}$ and formaldehyde, it can form larger cluster such as $\mathrm{M}_{4} \mathrm{H}^{+}\left(\mathrm{H}_{2} \mathrm{O}\right)_{3}$ in the same condition. Effect of basicity of $\mathrm{M}$ and $\mathrm{N}$ on the formation of their asymmetric dimer $\left(\mathrm{MH}^{+} \mathrm{N}\right)$ was investigated. It was found that the enthalpy of $\mathrm{MH}^{+} \mathrm{N}$ formation depends on the difference in the basicities of $\mathrm{M}$ and $\mathrm{N}$. The asymmetric dimer of 2ocatanone and acetophenone with comparable PA is formed easily with $\Delta \mathrm{H}$ of $-106 \mathrm{~kJ} / \mathrm{mol}$ while the $\Delta \mathrm{H}$ for formation of asymmetric dimer of 2-ocatanone and pyridine with $\Delta \mathrm{PA}$ of $94 \mathrm{~kJ} / \mathrm{mol}$ is $-85 \mathrm{~kJ} / \mathrm{mol}$.

\section{Acknowledgments}

This project has received funding from the European Union's Horizon 2020 research and innovation program under grant agreement No 692335 and Marie Skłodowska-Curie grant agreement no. 674911. This work was supported by the Slovak Research and Development Agency (contract no. APVV-0259-12 and APVV-15-0580) and the Slovak Grant Agency for Science (contract no. VEGA 1/0787/18). 


\section{References}

1. Jacquemin, D., Zuniga, J., Requena, A., Ceron-Carrasco, J.P.: Assessing the importance of proton transfer reactions in DNA. Acc. Chem. Res. 47, 2467-2474 (2014)

2. Lepine, F., Milot, S., Deziel, E., He, J., Rahme, L.G.: Electrospray/mass spectrometric identification and analysis of 4-hydroxy-2-alkylquinolines (HAQs) produced by Pseudomonas aeruginosa. J. Am. Soc. Mass Spectrom. 15, 862-869 (2004)

3. Wyttenbach, T., Bowers, M.T.: Hydration of biomolecules. Chem. Phys. Lett. 480, 1-16 (2009)

4. Elm, J., Passananti, M., Kurtén, T., Vehkamäki, H.: Diamines can initiate new particle formation in the atmosphere. J. Phys. Chem. A 121, 6155-6164 (2017)

5. Blake, R.S., Monks, P.S., Ellis, A.M.: Proton-transfer reaction mass spectrometry. Chem. Rev. 19, 861-896 (2009)

6. Valadbeigi, Y., Farrokhpour, H., Rouholahnejad, F., Tabrizchi, M.: Experimental and theoretical study of the kinetic of proton transfer reaction by ion mobility spectrometry. Int. J. Mass Spectrom. 369, 105-111 (2014)

7. Zhang, Q., Zou, X., Liang, Q., Wang, H., Huang, C., Shen, C., Chu, Y.: Ammonia-assisted proton transfer reaction mass spectrometry for detecting triacetone triperoxide (TATP) explosive. J. Am. Soc. Mass Spectrom. DOI: 10.1007/s13361-018-2108-6 (2018)

8. Meot-Ner (Mautner), M., Scheiner S., Yu, W.O.: Ionic hydrogen bonds in bioenergetics. 3. Proton transport in membranes, modeled by ketone/water clusters. J. Am. Chem. Soc. 120, 69806990 (1998)

9. Konig, S., Fales, H.M.: Formation and decomposition of water clusters as observed in triple quadrupole mass spectrometer. J. Am. Soc. Mass Spectrom. 9, 814-822 (1998)

10. Huang, C., Kresin, V.V., Pysanenko, A., Farnik, M.: Water cluster fragmentation probed by pickup experiments. J. Chem. Phys. 145, 104304 (2016)

11. Iyengar, S.S., Petersen, M.K., Day, T.J.F., Burnham, C.J., Teige V.E., Voth, G.A.: J. Chem. Phys. 123, 084309 (2005)

12. Sunner, J., Beech, I.B., Hiroka, K.: On the distribution of ion/neutral clusters in electrospray and laser spray-A cluster division model for the electrospray processes. J. Am. Chem. Mass Spectrom. 17, 151-162 (2006)

13. Postulka, J., Slavicek, P., Domaracka, A., Pysanenko, A., Farnik M., Kocisek, J.: Proton transfer from pinene stabilizes water clusters. Phys. Chem. Chem. Phys. DOI: 10.1039/C8CP05959D (2019)

14. Keesee, R.G., Castleman, A.W.: Thermochemical Data on Gas-Phase Ion-Molecule Association and Clustering Reactions. J. Phys. Chem. Ref. Data 15, 1011 (1986)

15. Kebarle, P.: Ion thermochemistry and solvation from gas phase ion equilibria. Annu. Rev. Phys. Chem. 28, 445-476 (1977) 
16. Meot-Ner (Mautner), M.: The ionic hydrogen bond and ion solvation. $1 . \mathrm{NH}^{+} \ldots \mathrm{O}, \mathrm{NH}^{+} \ldots \mathrm{N}$, and $\mathrm{OH}^{+} \ldots \mathrm{O}$ bonds. Correlations with proton affinity. Deviation due to structural effects. J. Am. Chem. Soc. 106, 1257-1264 (1984)

17. Valadbeigi, Y.: Proton affinities of hydrated molecules. Chem. Phys. Lett. 660, 301-306 (2016)

18. Valadbeigi, Y., Ilbeigi, V., Michalczuk, B., Sabo M., Matejcik, S.: Study of atmospheric pressure chemical ionization mechanism in corona discharge ion source with and without $\mathrm{NH}_{3}$ dopant by ion mobility spectrometry combined with mass spectrometry: A theoretical and experimental study. J. Phys. Chem. A 123, 313-322 (2019)

19. Demireva, M., O’Brien, J. T., Williams, E. R.: Water-induced folding of 1,7diammoniumheptane. J. Am. Chem. Soc., 134, 11216-11224 (2012)

20. Noh, D.H., Lee, S.J.C., Lee, J.W. Kim, H.I.: Host-guest chemistry in the gas phase: Complex formation of cucurbit[6]urcil with proton-bound water dimer. J. Am. Chem. Soc. Mass Spectrom. 25, 410-421 (2014)

21. Li, X., Wang, X., dell'Arco Passaro, M., Spinell, N., Apicella, B.: Insights on clusters formation mechanism by time of flight mass spectrometry. 1. The case of ethanol-water clusters. J. Am. Chem. Mass Spectrom. 26, 1665-1675 (2015)

22. Gao, B., Wyttenbach T., Bowers, M.T.: Hydration of protonated aromatic amino acids: Phenylalanine, tryptophan, and tyrosine. J. Am. Chem. Soc. 131, 4695-4701 (2009)

23. Kebarle, P.: A brief overview of the present status of the mechanisms involved in electrospray mass spectrometry. J. Mass Spectrom. 35, 804-817 (2000)

24. Li, J., Wei, W., Nye, L.C., Schulz, P. S., Wasserscheid, P., Ivanovic-Burmazovic I., Drewello, T.: Zwitterionic clusters with dianion core produced by electrospray ionisation of Brønsted acidic ionic liquids. Phys. Chem. Chem. Phys. 14, 5115-5121 (2012)

25. Valadbeigi, Y., Farrokhpour, H., Tabrizchi, M.: Effect of hydration on the kinetics of protonbound dimer formation: Experimental and theoretical study. J. Phys. Chem. A 118, 7663-7671 (2014)

26. Jacobs, A.D., Jose, K.V.J., Horness, R., Raghavachari, K., Thielges, M.C., Clemmer, D.E.: Cooperative formation of icosahedral proline clusters from dimers. J. Am. Chem. Soc. Mass Spectrom. 29, 95-102 (2018)

27. Wu, R., Marta, R.A., Martnes, J.K., Eldridge, K.R., McMahon, T.B.: Experimental and theoretical investigation of the proton-bound dimers of lysine. J. Am. Chem. Mass Spectrom. 22, 1651-1659 (2011)

28. Ewing, R.G., Eiceman, G. A., Stone, J.A.: Proton-bound cluster ions in ion mobility spectrometry. Int. J. Mass Spectrom. 193, 57-68 (1999)

29. Eiceman, G.A., Karpas, Z., Hill, Jr. H.H.: Ion Mobility Spectrometry. 3th Ed. CRC Press, FL, 2014.

30. Meot-Ner, M., Scheiner, S., Yu, W.O.: Ionic hydrogen bonds in bioenergetics. 3. Proton transport in membranes, modeled by ketone/water clusters. J. Am. Chem. Soc. 120, 6980-6990 (1998) 
31. Makinen, M., Sillanpaa, M., Viitanen, A.K., Knap, A., Makela, J.M., Puton, J.: The effect of humidity on sensitivity of amine detection in ion mobility spectrometry. Talanta, 84, 116-121 (2011)

32. Roscioli, J.R., McCunn, L.R., Johnson, M.A.: Quantum structure of the intermolecular proton bond. Science 316, 249-254 (2007)

33. Witt, M., Grutzmacher, H.F.: Proton bound homodimers and heterodimers of amides and amines in the gas phase. Equilibrium studies by Fourier transformation ion cyclotron resonance spectrometry. J. Am. Chem. Soc. Mass Spectrom. 13, 1273-1281 (2002)

34. Tan, J.A., Kuo, J. L.: A closer examination of the coupling between ionic hydrogen bond (IHB) stretching and flanking group motions in $\left(\mathrm{CH}_{3} \mathrm{OH}\right)_{2} \mathrm{H}^{+}$: the strong isotope effects. Phys. Chem. Chem. Phys. 18, 14531-14542 (2016)

35. Sabo M., Matejcik, S.: Corona discharge ion mobility spectrometry with orthogonal acceleration time of flight mass spectrometry for monitoring of volatile organic compounds. Anal. Chem. 84, 5327-5334 (2012)

36. Frisch, M.J., Trucks, G.W., Schlegel, H.B., Scuseria, G.E., Robb, M.A., Cheeseman, J.R., Scalmani, G., Barone, V., Mennucci, B., Petersson, G.A., Nakatsuji, H., Caricato, M., Li, X., Hratchian, H.P., Izmaylov, A.F., Bloino, J., Zheng, G., Sonnenberg, J.L., Hada, M., Ehara, M., Toyota, K., Fukuda, R., Hasegawa, J., Ishida, M., Nakajima, T., Honda, Y., Kitao, O., Nakai, H., Vreven, T., Montgomery, J.A., Jr., Peralta, J.E., Ogliaro, F., Bearpark, M., Heyd, J.J., Brothers, E., Kudin, K.N., Staroverov, V.N., Kobayashi, R., Normand, J., Raghavachari, K., Rendell, A., Burant, J.C., Iyengar, S.S., Tomasi, J., Cossi, M., Rega, N., Millam, J.M., Klene, M., Knox, J.E., Cross, J.B., Bakken, V., Adamo, C., Jaramillo, J., Gomperts, R., Stratmann, R.E., Yazyev, O., Austin, A.J., Cammi, R., Pomelli, C., Ochterski, J.W., Martin, R.L., Morokuma, K., Zakrzewski, V.G., Voth, G.A., Salvador, P., Dannenberg, J.J., Dapprich, S., Daniels, A.D., Farkas, O., Foresman, J.B., Ortiz, J.V., Cioslowski, J., Fox, D.J.: Gaussian 09, Revision A.1. Gaussian, Inc., Wallingford (2009)

37. Hunter, E.P.L., Lias, S.G.: Evaluated gas phase basicities and proton affinities of molecules: An update. J. Phys. Chem. Ref. Data 27, 413-656 (1998)

38. Valadbeigi Y., Farrokhpour, H.: DFT, CBS-Q, W1BD and G4MP2 calculation of the proton and electron affinities, gas phase basicities and ionization energies of saturated and unsaturated carboxylic acids $\left(\mathrm{C}_{1}-\mathrm{C}_{4}\right)$. Int. J. Quantum Chem. 113, 1717-1721 (2013)

39. Valadbeigi, Y.: Relationship between proton affinities and structures of proton-bound dimers. Eur. J. Mass Spectrom. 23, 55-63 (2017)

40. Valadbeigi, Y.: Superbasicity of 1,3,5-cycloheptatriene derivatives and their proton sponges in gas phase. Chem. Phys. Lett. 689, 1-7 (2017) 